\title{
KEEFEKTIFAN MODEL STUDENT FACILITATOR AND EXPLAINING BERBANTU MEDIA PAPAN KARTU TEMPEL TERHADAP HASIL BELAJAR KELAS IV
}

\author{
Sri Rahayu ${ }^{1}$, Qoriati Mushafanah ${ }^{2}$, Veryliana Purnamasari ${ }^{3}$ \\ Fakultas Ilmu Pendidikan, Universitas PGRI Semarang \\ email: srirahayu3497@gmail.com
}

\begin{abstract}
This research aimed to determine the effectiveness of the Student Facilitator and Explaining models with the help of the Paste Card media on the learning outcomes of the fourth grade students on the theme of My Story SDN 01 Gemuhblanten. The population were all fourth grade students of SDN 01 Gemuhblanten Kendal academic year 2018/ 2019. This research was an experimental study with a quantitative approach. The design of this study was a pre-experimental study with the type of research used is one group pretestposttest design that uses a sampling technique that is non probability sampling. Data collection techniques are carried out using interview, observation, documentation, and test techniques. Student learning outcomes are seen from the average pretest value of 59.00 and increase in the posttest value with an average of 83.37. From the calculation of t-test obtained $t_{\text {count }}$ greater than $t_{\text {table }}$ that is 20,391>2,101, then $H_{0}$ is rejected and $H_{a}$ is accepted. The conclusion is that the Student Facilitator and Explaining learning model is assisted by the media of the Paste Card Board effective on the learning outcomes of the fourth grade students on the theme of My Story SDN 01 Gemuhblanten.
\end{abstract}

Keywords: effectiveness, learning outcomes, SFAE model, media

\begin{abstract}
Abstrak
Penelitian ini bertujuan untuk mengetahui keefektifan model Student Facilitator and Explaining berbantu media Papan Kartu Tempel terhadap hasil belajar siswa kelas IV tema Cita-Citaku SDN 01 Gemuhblanten. Populasi dalam penelitian ini adalah seluruh siswa kelas IV SDN 01 Gemuhblanten Kendal tahun pelajaran 2018/ 2019. Penelitian ini merupakan penelitian eksperimen dengan pendekatan kuantitatif. Desain penelitian ini merupakan penelitian pre-eksperimen dengan jenis penelitian yang digunakan adalah one group pretest-posttest design yang menggunakan teknik sampling yaitu non probability sampling. Teknik pengumpulan data dilakukan dengan menggunakan teknik wawancara, observasi, dokumentasi, dan tes. Hasil belajar siswa dilihat dari rata-rata nilai pretest yaitu 59,00 dan meningkat pada nilai posttest dengan rata-rata 83,37. Dari perhitungan uji-t diperoleh $t_{\text {hitung }}$ lebih besar dari $t_{\text {tabel }}$ yaitu 20,391 > 2,101, maka $\mathrm{H}_{0}$ ditolak dan $\mathrm{H}_{\mathrm{a}}$ diterima. Kesimpulannya bahwa model pembelajaran Student Facilitator and Explaining berbantu media Papan Kartu Tempel efektif terhadap hasil belajar siswa kelas IV tema Cita-Citaku SDN 01 Gemuhblanten.
\end{abstract}

Kata Kunci : keefektifan, hasil belajar, model SFAE, media 


\section{PENDAHULUAN}

Undang-undang Nomor 20

Tahun 2003 tentang Sistem Pendidikan Nasional, dalam Pasal 1 Ayat 1 menyatakan bahwa pendidikan adalah usaha sadar dan terencana untuk mewujudkan suasana belajar dan proses pembelajaran agar peserta didik secara aktif mengembangkan potensi dirinya untuk memiliki kekuatan spiritual keagamaan, pengendalian diri, kepribadian, kecerdasan, akhlak mulia, serta keterampilan yang diperlukan dirinya, masyarakat, bangsa dan negara.

Menurut Shoimin (2014:15), sistem pendidikan di Indonesia harus difokuskan pada keberhasilan pada peserta didik dengan jaminan kemampuan yang diarahkan pada life skill yang di kemudian hari dapat menopang kesejahteraan peserta didik itu sendiri untuk keluarganya serta masa depannya dengan kehidupan yang layak di masyarakat. Untuk mewujudkan kehidupan masyarakat yang layak dalam sistem pendidikan di Indonesia saat ini, diperlukan adanya sumber daya manusia yang mempunyai peranan penting bagi kesuksesan dan keberhasilan dalam proses pendidikan. Sumber daya manusia yang dimaksud yaitu seorang guru yang berkompeten. Guru perlu melakukan suatu perhatian serta rancangan sedemikian rupa dalam proses pembelajaran yang ada agar tujuan pendidikan dapat tercapai. Pada saat ini, diperlukan suatu paradigma baru oleh seorang guru dalam proses pembelajaran, dari yang semula pembelajaran berpusat pada guru menuju pembelajaran yang inovatif dan berpusat pada siswa. Perubahan tersebut dimulai dari segi kurikulum, model pembelajaran, ataupun cara mengajar. Diperlukan paradigma revolusioner yang mampu menjadikan proses pendidikan sebagai pencetak sumber daya manusia yang berkualitas. Dalam perubahan kurikulum, cara mengajar harus mampu mempengaruhi perkembangan pendidikan karena pendidikan merupakan tolak ukur pembelajaran dalam lingkup sekolah.

Pada PP No. 32 Tahun 2013 merupakan hasil perubahan dari $\mathrm{PP}$ No. 19 Tahun 2005 yang menyatakan tentang Standar Nasional Pendidikan bahwa pemerintah sangat 
memperhatikan tentang sistem pendidikan. Dengan tujuan untuk menciptakan kecerdasan bagi seluruh rakyat Indonesia. Saat ini Indonesia menggunakan dua kurikulum yaitu kurikulum KTSP dan kurikulum 2013. Sedangkan pelaksanaan kurikulum di sekolah-sekolah saat ini ada yang sudah mengunakan kurikulum 2013 dan ada yang masih menggunakan kurikulum KTSP.

Di setiap proses pembelajaran pada sekolah, guru mempunyai peran penting untuk memberikan ilmu kepada siswa. Maka dari itu seorang guru harus mempunyai keterampilan dan keahlian dalam mengajar agar siswanya dapat dengan mudah mengerti setiap ilmu yang disampaikan oleh guru tersebut. Saat ini para pendidik baik di tingkat dasar hingga tingkat perguruan tinggi telah banyak memanfaatkan model dan media pembelajaran yang variatif guna memudahkan pendidik memberikan penjelasan kepada peserta didiknya. Melalui model dan media pembelajaran, pendidik dapat membantu peserta didik mendapatkan informasi, ide, keterampilan, cara berfikir dan mengekspresikan kreativitas. Penggunaan model dan media dalam proses pembelajaran diharapkan dapat menghidupkan jalannya pembelajaran di kelas sehingga tujuan pembelajaran yang ingin dicapai terpenuhi.

Joyce dan Weill (Huda, 2013: 72) mendeskripsikan bahwa model pembelajaran sebagai rencana atau pola yang dapat digunakan untuk membentuk kurikulum, mendesain materi-materi instruksional, dan memandu proses pengajaran di ruang kelas atau di setting berbeda. Sedangkan media pembelajaran adalah segala sesuatu yang dapat digunakan untuk menyalurkan pesan (bahan pembelajaran), sehingga dapat merangsang perhatian, minat, pikiran, dan perasaan siswa dalam kegiatan belajar untuk mencapai tujuan belajar (Daryanto, 2016: 6).

Berdasarkan data yang diperoleh dari wawancara dengan Bapak Dwi Sukamto selaku guru kelas IV di SDN 01 Gemuhblanten, dapat diketahui bahwa hasil belajar siswa dalam pembelajaran tematik masih rendah dimana 10 dari 19 jumlah siswa yang memperoleh nilai dibawah KKM, yaitu sebesar 53\% 
dari seluruh siswanya. Sedangkan, KKM pada pembelajaran tematik di SDN 01 Gemuhblanten yaitu 70 . Dapat dilihat dari perolehan hasil belajar tersebut bahwa tingkat ketuntasan hasil belajar siswa masih rendah, dimana masih terdapat setengah dari jumlah seluruh siswa di kelas IV yang belum mencapai batas ketuntasannya. Hasil belajar digunakan untuk mengukur sejauh mana siswa menguasai materi pelajaran yang disampaikan oleh gurunya tersebut. Dengan adanya tingkat hasil belajar yang tinggi maka penguasaan materi yang disampaikan oleh guru dapat diterima dengan baik oleh siswa. Proses belajar mengajar dapat dikatakan berhasil apabila seluruh peserta didik mampu memahami materi ajar dengan baik dan mendapatkan hasil belajar yang tinggi. Keberhasilan dalam proses belajar mengajar merupakan hal yang sangat diharapkan oleh semua pihak. Hasil belajar yang tinggi sangat diharapkan oleh siswa, guru maupun orang tua siswa.

Berdasarkan hasil wawancara dan observasi yang telah dilakukan, terlihat bahwa rendahnya hasil belajar siswa terjadi karena model pembelajaran yang dilaksanakan oleh guru di kelas masih menerapkan model pembelajaran langsung atau kurang mengarahkan siswa kearah pembelajaran berpusat pada siswa. Pembelajaran yang disampaikan oleh guru masih bersifat verbalistik (hafalan) dan penjelasan suatu konsep lebih banyak dilakukan secara tertulis dan secara lisan, sehingga peran aktif siswa dalam proses pembelajaran kurang diperhatikan. Hal ini mengakibatkan banyaknya siswa yang sering bosan pada saat proses pembelajaran sedang berlangsung dikarenakan model pembelajaran semacam ini kurang menarik. Siswa merasa guru hanya sebatas ceramah di depan kelas tanpa adanya kreativitas model pembelajaran yang lain. Siswa terkesan hanya duduk diam mendengarkan penjelasan dari guru karena tidak ada kegiatan yang menarik minat siswa. Untuk itu, diperlukan adanya sebuah model yang senantiasa mudah diterapkan dan dapat dikembangkan oleh guru untuk melatih siswa berpikir dalam hal menemukan sendiri pembelajaran yang didapat serta dapat menarik 
perhatian siswa agar dapat lebih aktif mengikuti pembelajaran. Guru perlu menerapkan model yang inovatif, efektif serta edukatif dalam pembelajaran agar dapat menarik minat siswa untuk mengikuti pembelajaran, sehingga siswa tidak merasa bosan dan lebih fokus pada saat mengikui proses pembelajaran. Selain itu, guru juga kurang menggunakan media pembelajaran yang menarik siswa dalam memahami materi pembelajaran yang disampaikan oleh guru juga menjadi masalah yang terjadi di kelas. Penggunaan media pembelajaran dalam proses pembelajaran diterapkan agar dapat membantu siswa dalam memahami materi pembelajaran yang disampaikan oleh guru dengan mudah. Maka disimpulkan bahwa untuk membantu siswa dalam memahami materi pembelajarasn dibutuhkan sebuah model dan media pembelajaran yang kreatif, efektif dan efesien agar hasil belajar yang diperoleh siswa menjadi lebih baik.

Model pembelajaran yang dipilih harus mampu membangkitkan motivasi atau gairah baik bagi peserta didik maupun bagi guru dalam proses pembelajaran sehingga dapat mencapai tujuan pembelajaran yang diinginkan dan memaksimalkan hasil belajar siswa. Salah satunya model pembelajaran yang dapat dipakai yaitu model Student Facilitator and Explaining. Model pembelajaran Student Facilitator and Explaining merupakan rangkai penyajian materi ajar yang diawali dengan penjelasan secara terbuka, memberi kesempatan siswa untuk menjelaskan kembali kepada rekan-rekannya, dan diakhiri dengan penyampaian semua materi kepada siswa (Huda, 2013: 228).

Pelaksanaan model pembelajaran harus disertai atau dibarengi juga dengan media yang akan digunakan. Media pembelajaran yang tepat membuat pembelajaran yang diselenggarakan menjadi lebih optimal, menjadikan kompetensi yang ditetapkan lebih mudah untuk dicapai. Itulah mengapa peneliti memberikan solusi berupa model Student Facilitator and Explaining berbantu media Papan Kartu Tempel. Media papan kartu tempel merupakan media yang terdiri atas kartu-kartu yang diletakkan di sebuah papan tempel. 
Menurut Daryanto (2016:22) menjelaskan bahwa papan tempel adalah sebilah papan yang fungsinya sebagai tempat untuk menempelkan pesan atau suatu tempat untuk menyelenggarakan suatu display yang merupakan bagian dari aktivitas penting suatu sekolah. Dalam hal ini, media papan kartu tempel yaitu media yang berupa papan yang dapat ditempel dengan kartu yang berisi materi pelajaran yang akan disampaikan.

Penelitian yang dilakukan oleh Dian Idata Tarenda, Qoriati Mushafanah, dan Muhajir (2018) terbukti bahwa model Student Facilitator and Explaining berbantu media diorama efektif terhadap hasil belajar IPS siswa kelas III SD Negeri 3 Purwareja Klampok. Hal ini sesuai dengan kriteria keefektifan yang terdapat dalam aspek, bahwa terjadi peningkatan hasil belajar IPS kelas III SD Negeri 3 Purwareja Klampok sebelum dan sesudah perlakuan. Hal ini berdasarkan analisis data hasil penelitian dengan menggunakan paired t-test pihak kiri di peroleh | $t_{\text {hitung }}>t_{\text {tabel }}$ yaitu $t_{\text {hitung }}=-32,209$ dan $\mathrm{t}_{\text {tabel }}=1,729$, dan hasil belajar siswa mencapai kriteria ketuntasan belajar siswa melalui nilai posttest sebanyak 20 siswa $100 \%$ telah mencapai ketuntasan minimal individu sebagai hasil dari penggunaan model Student Facillitator and Explaining berbantu media diorama.

Berdasarkan pada uraian latar belakang masalah di atas, maka peneliti bermaksud untuk melakukan penelitian dengan judul "Keefektifan Model Student Facilitator and Explaining Berbantu Media Papan Kartu Tempel terhadap Hasil Belajar Siswa Kelas IV Tema Cita-Citaku SDN 01 Gemuhblanten”.

\section{METODE PENELITIAN}

Penelitian ini menggunakan metode penelitian kuantitatif. Menurut Sugiyono (2016:14) menyatakan bahwa metode penelitian kuantitatif adalah metode penelitian yang berdasarkan filsafat positivisme, digunakan untuk meneliti pada populasi atau sampel tertentu, teknik pengambilan sampel pada dasarnya dilakukan secara random, pengumpulan data menggunakan instrumen penilaian, analisis data bersifat kuantitatif atau statistik 
dengan tujuan untuk menguji penelitian ini diambil dari satu kelas hipotesis yang telah ditetapkan. yaitu kelas IV SDN 01 Metode penelitian yang digunakan Gemuhblanten. Teknik sampling yang adalah metode penelitian eksperimen. digunakan yaitu non probability Sugiyono (2016:107) menyatakan sampling dengan jenis sampling bahwa metode penelitian eksperimen jenuh. dapat diartikan sebagai metode penelitian yang digunakan untuk mencari pengaruh perlakuan tertentu terhadap yang lain dalam kondisi terkendali. Pada penelitian ini, desain penelitian yang digunakan adalah preexperimental designs. Jenis penelitian yang diambil adalah menggunakan One-Group Pretest-Posttest Design. Rancangan ini menggunakan satu kelompok sasaran. Sugiyono (2016: 110) menyatakan bahwa pada desain ini terdapat pretest, sebelum diberi perlakuan.

Menurut Arikunto (2013: 173) menyatakan bahwa populasi adalah keseluruhan subjek penelitian. apabila seseorang ingin meneliti semua elemen yang ada dalam wilayah penelitian, maka penelitiannya merupakan penelitian populasi. Populasi pada penelitian ini yaitu seluruh siswa kelas IV SDN 01 Gemuhblanten yang berjumlah 19 siswa. Sedangkan sampel dari

Penelitian ini menggunakan beberapa teknik pengumpulan data diantaranya yaitu wawancara, observasi, dokumentasi, dan tes. Wawancara dilakukan dengan guru kelas IV SDN 01 Gemuhblanten yaitu Bapak Dwi Sukamto, S.Pd.SD untuk menemukan permasalahan awal yang terdapat di Sekolah Dasar tersebut. Kegiatan observasi dilakukan peneliti dengan mengamati kegiatan belajar mengajar yang dilakukan guru di dalam untuk memperoleh data-data hasil belajar dan keadaan siswa saat pembelajaran tematiknya. Dokumentasi dalam penelitian ini digunakan untuk mendapatkan daftar nama siswa, hasil ulangan harian siswa, serta foto-foto pada saat proses kegiatan penelitian berlangsung. Pada penelitian ini, tes akan diberikan dua kali untuk mengukur hasil belajar tematik siswa. Tes awal (pretest) akan diberikan sebelum diberikan perlakuan dengan 
model Student Facilitator and Explaining berbantu media Papan Kartu Tempel, sedangkan tes kedua diberikan di akhir pembelajaran (posttest) setelah diberikan perlakuan dengan menggunakan model Student Facilitator and Explaining berbantu media Papan Kartu Tempel. Bentuk tes yang digunakan berupa soal pilihan ganda.

Sebelum soal tes digunakan, soal tes perlu diujicobakan terlebih dahulu. Pelaksanaan uji coba ini dimaksudkan untuk mengetahui validitas, reliabilitas, tingkat kesukaran, dan daya pembeda pada butir soal. Hasil uji coba yang telah diperoleh, maka dapat dipilih soal yang digunakan untuk mengukur hasil belajar siswa kelas IV tema CitaCitaku. Berdasarkan hasil uji coba diperoleh bahwa dari 50 soal yang diujicobakan 30 soal masuk kriteria valid dan dijadikan sebagai soal pretest dan posttest.

Penelitian ini terdapat 2 variabel yaitu variabel bebas dan variabel terikat. Variabel bebas (independen) merupakan variabel yang menjadi sebab timbulnya variabel terikat (dependen). Variabel bebas dalam penelitian ini yaitu model Student Facilitator and Explaining berbantu media Papan Kartu Tempel yang diterapkan dalam pembelajaran tema Cita-Citaku kelas IV. Sedangkan variabel terikat (dependen) merupakan variabel yang dipengaruhi atau yang menjadi akibat karena adanya variabel bebas. Variabel terikat dalam penelitian ini yaitu hasil belajar siswa kelas IV tema Cita-Citaku SDN 01 Gemuhblanten Kabupaten Kendal tahun ajaran 2018/ 2019 setelah diterapkan model Student Facilitator and Explaining berbantu media Papan Kartu Tempel. Hasil belajar ini akan ditunjukkan melalui hasil posttest.

Teknik analisis data yang akan digunakan dalam penelitian ini melalui beberapa tahapan sebagai berikut; (1) Uji normalitas awal (pretest) digunakan untuk mengetahui data yang akan dianalisis berdistribusi normal atau tidak normal sebelum diberi perlakuan. Hal ini untuk menemukan uji statistik selanjutnya. Rumus yang digunakan adalah uji liliefors; (2) Uji normalitas akhir (posttest) digunakan untuk mengetahui data yang akan dianalisis 
Jurnal Sinektik

Volume 2 Nomor 2, Edisi Desember 2019

Prodi PGSD Universitas Slamet Riyadi

ISSN 2620-6560 (print) ISSN 2620-746X (online)

berdistribusi normal atau tidak normal setelah diberilakan perlakuan menggunakan model pembelajaran Student Facilitator and Explaining. Hal ini dilakukan untuk menemukan uji statistik selanjutnya;; (3) Uji ketuntasan hasil belajar, dalam penelitian ini dicari ketuntasan belajar individu siswa dan ketuntusan belajar klasikalnya; (4) Uji hipotesis, dalam penelitian ini menggunakan uji t-test.

\section{HASIL DAN PEMBAHASAN}

Penelitian ini dilaksanakan di SDN 01 Gemuhblanten Kabupaten Kendal. Sampel pada penelitian ini adalah siswa kelas IV yang berjumlah 19 siswa terdiri dari 8 siswa laki-laki dan 11 siswa perempuan. Penelitian ini menggunakan model Student Facilitator and Explaining berbantu media Papan Kartu tempel yang diterapkan pada pembelajaran tema Cita-Citaku subtema Aku dan CitaCitaku. Desain pre-ekperimental yang digunakan dalam penelitian adalah jenis one-group pretest-postest design. Melalui penggunaan desain one-group pretest-postest design, maka hasil perlakuan dapat diketahui lebih akurat karena dapat dibandingkan dengan keadaan sebelum diberi perlakuan. Sebelum siswa diberi perlakuan menggunakan model Student Facilitator and Explaining berbantu media Papan Kartu Tempel, siswa mengerjakan pretest untuk mengetahui tingkat pemahaman siswa tentang materi yang diberikan. Selanjutnya untuk proses pembelajaran menggunakan model Student Facilitator and Explaining berbantu media Papan Kartu Tempel sesuai dengan materi pada tema Cita-Citaku subtema Aku dan Cita-Citaku pada pembelajaran 14. Setelah diberi perlakuan dengan menggunakan model Student Facilitator and Explaining berbantu media Papan Kartu Tempel tersebut, siswa diberikan post-test untuk mengetahui hasil belajarnya. Diharapkan dengan adanya perlakuan kondisi akhir dapat terpenuhi yaitu hasil belajar siswa menjadi meningkat. Alat pengumpulan data yang digunakan adalah tes bentuk pilihan ganda. Dikarenakan hanya menggunakan satu sampel maka hipotesis didasarkan perbedaan pada sebelum diberi perlakuan dan setelah diberi perlakuan dengan 
menggunakan model Student

Facillitator and Explaining berbantu media Papan Kartu tempel. Pretest dilakukan untuk memperoleh data awal, dan Posttest dilakukan untuk memperoleh data akhir. Setelah pretest dan post-test dilakukan data yang diperoleh kemudian dianalisis untuk mengetahui keefektifan dari model Student Facillitator and Explaining berbantu media Papan Kartu Tempel melalui rerataan sebelum diberi perlakuan dan setelah diberi perlakuan. Soal yang digunakan untuk mengukur pretest dan posttest adalah soal pilihan ganda yang berjumlah 30 soal dan sudah di uji validitas, reliabilitas, daya pembeda, serta tingkat kesukaran.

Data yang sudah diperoleh dari hasil pretest dan posttest selanjutnya dilakukan uji normalitas untuk mengetahui bahwa kelas penelitian berasal dari data yang berdistribusi normal. Data penelitian hasil belajar pretest dan posttest disajikan dalam tabel 1 berikut ini.
Tabel 1. Nilai Pretest dan Posttest Siswa Kelas IV SDN 01 Gemuhblanten

\begin{tabular}{lcc}
\hline \multicolumn{1}{c}{ Keterangan } & Pretest & $\begin{array}{c}\text { Posttes } \\
\boldsymbol{t}\end{array}$ \\
\hline Nilai Terendah & 43 & 63 \\
Nilai Tertinggi & 77 & 100 \\
Jumlah & 1121 & 1584 \\
Rata-rata & 59,00 & 83,37 \\
Jumlah Siswa Tuntas & 5 & 17 \\
Jumlah Siswa Tidak & 14 & 2 \\
Tuntas & & \\
\hline Sumber: Data Hasil Penelitian (2019) &
\end{tabular}

Berdasarkan Tabel 1 di atas dapat dilihat bahwa selisih nilai pretest tertinggi dan terendah berbeda. Nilai tertinggi pretest yaitu 77, sedangkan nilai terendah pretest adalah 43. Nilai rata-rata pretest yaitu 59,00 dan hanya terdapat 5 siswa yang tuntas. Hal tersebut menunjukkan bahwa nilai pada pretest masih rendah dan belum mencapai Kriteria Ketuntasan Minimum (KKM) yaitu 70. Perbandingan antara nilai pretest yang dilakukan sebelum pembelajaran dengan nilai posttest yang diperoleh pada akhir pembelajaran dan setelah diberikan perlakuan dengan model Student Facilitator and Explaining berbantu media Papan Kartu Tempel mengalami kenaikan atau peningkatan. Seperti yang terlihat pada tabel 1 , nilai posttest tertinggi yaitu 100 , dan terendah 63 , dengan 
nilai rata-rata 83,37 dan sebanyak 17 siswa telah mencapai Kriteria Ketuntasan Minimum (KKM), hanya 2 siswa yang belum tuntas. Hal tersebut menunjukkan bahwa terdapat peningkatan dari nilai pretest yang sebelum diberikan perlakuan dengan nilai posttest yang sudah diberikan perlakuan dengan menggunakan model Student Facilitator and Explaining berbantu media Papan Kartu Tempel pada proses pembelajarannya. Peningkatan hasil belajar siswa kelas IV pada tema "Cita-Citaku" subtema "Aku dan Cita-Citaku" pembelajaran 1-4 tersebut ditandai dengan nilai ratarata posttest lebih besar dari pretest yaitu $83,37>59,00$.

Setelah memperoleh data hasil nilai pretest dan posttest kemudian melakukan analisis data awal dengan melakukan uji normalitas data. Uji normalitas digunakan untuk mengetahui data yang akan dianalisis berdistribusi normal atau tidak. Pada uji normalitas data yang akan diuji adalah data nilai pretest dan nilai posttest. Uji data ini akan menggunakan rumus Liliefors.
Tabel 2. Hasil Uji Normalitas Data Awal

\begin{tabular}{cc}
\hline Data & Pretest \\
\hline $\mathrm{L}_{0}$ & 0,1542 \\
$\mathrm{~L}_{\text {tabel }}$ & 0,195 \\
$\mathrm{~N}$ & 19 \\
$\mathrm{~A}$ & 0,05 \\
Kesimpulan & Berdistribusi normal
\end{tabular}

Sumber: Analisis Hasil Penelitian (2019)

Hasil pengujian normalitas data awal pada tabel 2 menunjukan bahwa hasil pretest menunjukkan $\mathrm{L}_{0}=$ 0,1542 dan $\mathrm{L}_{\text {tabel }}=0,195$. Jadi sampel berasal dari distribusi normal karena $\mathrm{L}_{0}<\mathrm{L}_{\text {tabel. }}$ Sedangkan dari hasil posttest menunjukan $\mathrm{L}_{0}=0,1106$ dan $\mathrm{L}_{\text {tabel }}=0,195$. Jadi sampel berasal dari distribusi normal karena $\mathrm{L}_{0}<\mathrm{L}_{\text {tabel }}$. Perhitungan yang digunakan untuk mengetahui normalitas sampel dari populasi dilakukan dengan menggunakan uji Lilliefors, pada taraf signifikansi $5 \%$ dan $\mathrm{n}=19$.

Tabel 3. Hasil Uji Normalitas Data Posttest

\begin{tabular}{cc}
\hline Data & Posttest \\
\hline $\mathrm{L}_{0}$ & 0,1106 \\
$\mathrm{~L}_{\text {tabel }}$ & 0,195 \\
$\mathrm{~N}$ & 19 \\
$\alpha$ & 0,05
\end{tabular}

Kesimpulan Berdistribusi normal Sumber: Analisis Hasil Penelitian (2019)

Berdasarkan hasil pengujian normalitas data posttest pada tabel 3 diperoleh nilai $\mathrm{L}_{0}=0,1106$ dengan taraf signifikan 0,05 dan jumlah $\mathrm{n}=$ 19 dari daftar nilai kritis L maka diperoleh $\mathrm{L}_{\text {tabel }}=0,195$. Karena $\mathrm{L}_{0}<$ $\mathrm{L}_{\text {tabel }}$ yaitu $0,1106<0,195$ maka $\mathrm{H}_{0}$ 
diterima, sehingga data yang diperoleh berdistribusi normal.

\begin{tabular}{clcc}
\multicolumn{4}{c}{ Tabel 4. Analisis Ketuntasan Belajar } \\
\hline No. & \multicolumn{1}{c}{ Kriteria } & Pretest & Posttest \\
\hline 1. & Nilai Tertinggi & 77 & 100 \\
2. & Nilai Terendah & 43 & 63 \\
3. & Rata-rata & 59,00 & 83,37 \\
4. & Siswa Tuntas & 5 & 17 \\
5. & Siswa Tidak Tuntas & 14 & 2 \\
\hline \multicolumn{4}{l}{ Sumber: Analisis Hasil Penelitian (2019) }
\end{tabular}

Berdasarkan hasil penelitian menunjukkan bahwa pembelajaran setelah diberi perlakuan lebih baik dari pada sebelum diberi perlakuan. Hasil ketuntasan belajar siswa menunjukkan bahwa hasil akhir yang diperoleh siswa pada nilai pretest terdapat 14 siswa yang tidak mencapai KKM dan hanya 5 siswa yang mencapai KKM, dengan ratarata nilai kelas 59,00. Sedangkan hasil siswa pada nilai posttest lebih baik karena sebanyak 17 siswa yang telah mencapai KKM dan hanya terdapat 2 siswa yang tidak tuntas KKM, dengan rata-rata nilai kelas 83,37. Pada ketuntasan belajar siswa secara klasikal juga mengalami peningkatan, dibuktikan dengan hasil belajar siswa sebelum diberi perlakuan (pretest) yang menunjukan pembelajaran tanpa menggunakan model Student Facilitator and Explaining berbantu media Papan
Kartu Tempel hanya terdapat 5 siswa yang tuntas dengan persentase $26,32 \%$ dan 14 siswa yang belum tuntas dengan persentase $73,68 \%$. Sedangkan setelah diberi perlakuan (posttest) dengan menggunakan model Student Facilitator and Explaining berbantu media Papan Kartu Tempel jumlah siswa yang tuntas yaitu 17 siswa dan hanya 2 siswa yang tidak tuntas KKM. Dengan begitu, dapat dikatakan bahwa ketuntasan belajar klasikal kelas tersebut dengan hasil persentase $89,47 \%$ dapat dinyatakan tuntas secara klasikal.

Setelah diketahui bahwa data dari hasil pretest dan posttest berditribusi normal, maka langkah selanjutnya yaitu melakukan uji hipotesis. Uji hipotesis pada penelitian ini, peneliti menggunakan uji t-test yang dilakukan untuk membandingkan hasil data pretest dan posttest serta menentukan ada atau tidaknya perbedaan sebagai akibat dari perlakuan $\mathrm{X}$ yaitu pembelajaran dengan menggunakan model Student Facilitator and Explaining berbantu media Papan Kartu Tempel maka dianalisis dengan 
Jurnal Sinektik

Volume 2 Nomor 2, Edisi Desember 2019

Prodi PGSD Universitas Slamet Riyadi

ISSN 2620-6560 (print) ISSN 2620-746X (online)

menggunakan uji t-test. Hipotesis yang diajukan dalam penelitian ini adalah model pembelajaran Student Facilitator and Explaining berbantu media Papan Kartu Tempel efektif terhadap hasil belajar siswa kelas IV tema Cita-Citaku SDN 01 Gemuhblanten.

Tabel 5. Analisis Uji t-test

\begin{tabular}{ccccc}
\hline d.b & $\begin{array}{c}\text { Taraf } \\
\text { Sig. }\end{array}$ & $\mathbf{t}_{\text {hitung }}$ & $\mathbf{t}_{\text {tabel }}$ & Keterangan \\
\hline 18 & $5 \%$ & 20,391 & 2,101 & $\begin{array}{c}\mathrm{H}_{0} \\
\text { ditolak }\end{array}$ \\
\hline
\end{tabular}

Sumber: Analisis Hasil Penelitian (2019)

Kriteria pengujian $\mathrm{H}_{\mathrm{a}}$ diterima apabila $t_{\text {hitung }}>t_{\text {tabel }}$ dengan $\mathrm{db}=\mathrm{N}-1$ dengan taraf signifikan 5\% dan untuk harga $t_{\text {hitung }}<t_{\text {tabel }}$ maka $\mathrm{H}_{0}$ diterima. Setelah dilakukan analisis data nilai hasil belajar pada nilai pengetahuan diperoleh rata-rata untuk pretest sebesar 59,00 dan posttest sebesar 83,37 dengan $\mathrm{N}=19$ jadi $\mathrm{d} \cdot \mathrm{b}=19-1$ $=18$ yang diperoleh $t_{\text {hitung }}=20,391$ dengan taraf signifikan 5\% didapat nilai $t_{\text {tabel }}=2,101$. Karena $t_{\text {hitung }}>t_{\text {tabel }}$ yaitu 20,391 > 2,101 maka $\mathrm{H}_{\mathrm{a}}$ diterima, sehingga dapat disimpulkan bahwa model Student Facilitator and Explaining berbantu media Papan Kartu Tempel efektif terhadap hasil belajar siswa kelas IV tema CitaCitaku SDN 01 Gemuhblanten.
Berdasarkan hasil penelitian menunjukkan bahwa pembelajaran setelah diberi perlakuan lebih baik dari pada sebelum diberi perlakuan. Hasil ketuntasan belajar siswa menunjukkan bahwa hasil akhir yang diperoleh siswa pada nilai pretest terdapat 14 siswa yang tidak mencapai KKM dan hanya 5 siswa yang mencapai KKM, dengan ratarata nilai kelas 59,00. Sedangkan hasil siswa pada nilai posttest lebih baik karena sebanyak 17 siswa yang telah mencapai KKM dan hanya terdapat 2 siswa yang tidak tuntas $\mathrm{KKM}$, dengan rata-rata nilai kelas 83,37. Pada ketuntasan belajar siswa secara klasikal juga mengalami peningkatan, dibuktikan dengan hasil belajar siswa sebelum diberi perlakuan (pretest) yang menunjukan pembelajaran tanpa menggunakan model Student Facilitator and Explaining berbantu media Papan Kartu Tempel hanya terdapat 5 siswa yang tuntas dengan persentase $26,32 \%$ dan 14 siswa yang belum tuntas dengan persentase $73,68 \%$. Sedangkan setelah diberi perlakuan (posttest) dengan menggunakan model Student Facilitator and 
Explaining berbantu media Papan Kartu Tempel jumlah siswa yang tuntas yaitu 17 siswa dan hanya 2 siswa yang tidak tuntas KKM. Dengan begitu, dapat dikatakan bahwa ketuntasan belajar klasikal kelas tersebut dengan hasil persentase $89,47 \%$ dapat dinyatakan tuntas secara klasikal.

Uji t menyatakan bahwa untuk $\mathrm{n}=19$ dan taraf signifikansi 5\%, dengan $\mathrm{db}=\mathrm{n}-1=19-1=18$, diperoleh $t_{\text {hitung }}=20,391$ dan $t_{\text {tabel }}=$ 2,101. Dari data tersebut dapat disimpulkan bahwa $t_{\text {hitung }}>t_{\text {tabel }}$, sehingga $\mathrm{H}_{0}$ ditolak. Artinya, hal ini menunjukkan bahwa ada peningkatan hasil belajar siswa kelas IV SDN 01 Gemuhblanten tema Cita-Citaku dengan menggunakan model Student Facillitator and Explaining berbantu media Papan Kartu Tempel. Sehingga dapat disimpulkan bahwa model Student Facilitator and Explaining berbantu media Papan Kartu Tempel efektif terhadap hasil belajar siswa kelas IV tema Cita-Citaku SDN 01 Gemuhblanten.

Penelitian ini sesuai dengan hasil penelitian yang telah dilakukan oleh Dian Idata Tarenda, Qoriati
Mushafanah, dan Muhajir (2018) terbukti bahwa model Student Facilitator and Explaining berbantu media diorama efektif terhadap hasil belajar IPS siswa kelas III SD Negeri 3 Purwareja Klampok. Hal ini sesuai dengan kriteria keefektifan yang terdapat dalam aspek, bahwa terjadi peningkatan hasil belajar IPS kelas III SD Negeri 3 Purwareja Klampok sebelum dan sesudah perlakuan. Hal ini berdasarkan analisis data hasil penelitian dengan menggunakan paired t-test pihak kiri diperoleh $t_{\text {hitung }} \mid>t_{\text {tabel }}$ yaitu $t_{\text {hitung }}=-32,209$ dan $\mathrm{t}_{\text {tabel }}=1,729$, dan hasil belajar siswa mencapai kriteria ketuntasan belajar siswa melalui nilai posttest sebanyak 20 siswa $100 \%$ telah mencapai ketuntasan minimal individu sebagai hasil dari penggunaan model Student Facilitator and Explaining berbantu media diorama.

Berdasarkan penelitian ini dapat disimpulkan bahwa model Student Facilitator and Explaining berbantu media Papan Kartu Tempel pada tema Cita-Citaku subtema aku dan CitaCitaku pembelajaran 1-4 kelas IV SDN 01 Gemuhblanten dapat meningkatkan ketuntasan hasil belajar 
siswa. Perubahan tersebut diartikan terjadinya peningkatan dan pengembangan yang lebih baik dibandingkan dengan sebelumnya, misal dari tidak tahu menjadi tahu. Hasil belajar siswa menggunakan model pembelajaran Student Facillitator and Explaining berbantu media Papan Kartu Tempel ini menjadi lebih baik karena siswa lebih paham terhadap materi yang dipelajari karena terlibat langsung dalam pembelajaran sehingga menciptakan pembelajaran bermakna karena suasana belajar yang menyenangkan.

Hal ini sejalan dengan yang dijelaskan oleh Huda (2013: 228) bahwa model pembelajaran Student Facilitator and Explaining merupakan rangkai penyajian materi ajar yang diawali dengan penjelasan secara terbuka, memberi kesempatan siswa untuk menjelaskan kembali kepada rekan-rekannya, dan diakhiri dengan penyampaian semua materi kepada siswa. Pembelajaran ini efektif untuk melatih siswa berbicara dan menyampaikan ide, gagasan atau pendapatnya sendiri. Teknik pembelajaran ini memotivasi semua siswa untuk aktif dan memberi kesempatan pada siswa untuk mengajar temannya dan mempelajari sesuatu dengan baik pada waktu yang sama, serta dapat membuat pertanyaan dan mengemukakan pendapat. Penggunaan media Papan Kartu Tempel dapat membantu siswa dalam memahami materi pelajaran dalam proses kegiatan pembelajaran. Media Papan Kartu Tempel merupakan media berbantu yang didalamnya memberikan gambaran tentang materi yang ada pada tema Cita-Citaku subtema Aku dan CitaCitaku pembelajaran 1 sampai dengan pembelajaran 4 sehingga dapat membantu siswa dalam menjelaskan tentang materi tersebut kepada temantemannya sesuai dengan langkahlangkah model Student Facilitator and Explaining. Dalam proses pembelajaran pada tema Cita-Citaku subtema Aku dan Cita-Citaku pembelajaran 1-4 yang menggunakan model Student Facilitator and Explaining berbantu media Papan Kartu Tempel mencakup tiga aspek yaitu kognitif, afektif, dan psikomotorik. 
Dari hasil penelitian yang menunjukkan adanya keefektifan model Student Facilitator and Explaining berbantu media Papan Kartu Pintar terhadap hasil belajar siswa kelas IV tema Cita-Citaku SDN 01 Gemuhblanten salah satunya ada keterkaitan dan dipengaruhi oleh teori belajar. Faktor teori belajar sangat berpengaruh terhadap bagaimana siswa belajar. Teori belajar salah satu upaya untuk menggambarkan bagaimana seseorang belajar. Beberapa teori belajar yang berhubungan dengan penelitian ini adalah Teori Kognitivistik dan Teori Konstruktivistik.

Teori kognitivistik adalah teori belajar yang mengutamakan kepercayaan sepenuhnya yang diberikan kepada siswa yang menekankan proses belajar daripada hasil belajar. Siswa diberi kepercayaan salah satunya untuk memahami materi secara mandiri. Teori ini tidak hanya sekedar stimulus dan respon akan tetapi melibatkan proses berfikir siswa. Keterkaitan penelitian di kelas IV SDN 01 Gemuhblanten dengan menggunakan model Student Facilitator and
Explaining berbantu media Papan Kartu Tempel pada tema Cita-Citaku subtema Aku dan Cita-Citaku pembelajaran 1-4 dengan teori Kognitivistik adalah dilihat dari proses keaktifan siswa kelas IV pada saat proses pembelajaran ketika siswa mengerjakan soal yang diberikan oleh guru, siswa menjawab soal yang diberikan dengan melibatkan proses berfikir tidak hanya sekedar hubungan stimulus dan respon saja. Selain itu, siswa dalam proses pembelajaran lebih mengutamakan proses belajarnya. Salah satunya pada saat siswa menjelaskan dan menyampaikan pengetahuan ataupun pendapatnya mengenai materi pembelajaran dengan menggunakan kartu-kartu yang ditempelkan di Papan Kartu Tempel dengan sesuai dan baik di depan teman-temannya. Materi dalam proses pembelajaran juga hendaknya dikaitkan dengan kehidupan nyata sehari-hari oleh siswa, sehingga pengetahuan yang sebelumnya dimiliki akan semakin bertambah sesudah adanya proses belajar. Apabila dalam kegiatan belajar lebih mengutamakan 
prosesnya maka hasil belajarpun akan memperoleh hasil yang maksimal.

Sedangkan teori

konstruktivistik adalah teori belajar yang menjelaskan bahwa seseorang belajar berdasarkan pengalaman yang sudah terjadi. Dari adanya berbagai pengalaman maka seseorang akan mampu belajar dan mengambil kesimpulan dari pengalaman yang terjadi hal penting dalam teori ini yang dikaitkan dengan pembelajaran adalah bahwa siswa hendaknya berpartisipasi aktif dalam mengembangkan pengetahuan mereka, bukan guru ataupun orang lain. Keterkaitan penelitian di kelas IV SDN 01 Gemuhblanten dengan menggunakan model Student Facilitator and Explaining berbantu media Papan Kartu Tempel pada tema Cita-Citaku subtema Aku dan CitaCitaku pembelajaran 1-4 dengan teori Konstruktivistik adalah dapat dilihat dari proses belajar yang mengutamakan keterlibatan siswa secara aktif dalam kegiatan pembelajaran di kelas. Kegiatan pembelajaran yang dilakukan oleh siswa secara aktif dengan menyampaikan penjelasan dan pendapatnya di depan kelas akan lebih berkesan bermakna bagi siswa sendiri. Selain siswa yang harus berpartisipasi aktif peran guru juga harus ada di antara yaitu berperan sebagai mediator, fasilitator untuk membantu anak didiknya yang mengalami kesulitan dalam memahami materi.

\section{SIMPULAN}

Berdasarkan rumusan masalah, pengajuan hipotesis, analisis data dan pembahasan, maka peneliti membuat kesimpulan bahwa model pembelajaran Student Facilitator and Explaining berbantu media Papan Kartu Tempel efektif terhadap hasil belajar siswa kelas IV tema CitaCitaku SDN 01 Gemuhblanten. Hal itu dibuktikan dengan diperolehnya nilai pretest dengan rata-rata 59,00 mencapai ketuntasan $26,32 \%$ atau 5 siswa yang tuntas dan 73,68\% atau 14 siswa tidak tuntas. Dan hasil posttest dengan rata-rata 83,37 mencapai ketuntasan 89,47\% atau sebanyak 17 siswa yang tuntas KKM dan hanya terdapat 2 siswa yang tidak tuntas KKM. Dari perhitungan uji-t diperoleh $t_{\text {hitung }}$ sebesar 20,391 dan $\mathrm{t}_{\text {tabel }}$ sebesar 2,101 atau thitung lebih 
besar dari ttabel yaitu 20,391> 2,101, maka $\mathrm{H}_{0}$ ditolak dan $\mathrm{H}_{\mathrm{a}}$ diterima sehingga dapat disimpulkan bahwa model pembelajaran Student Facilitator and Explaining berbantu media Papan Kartu Tempel efektif terhadap hasil belajar siswa kelas IV tema Cita-Citaku SDN 01 Gemuhblanten.

Berdasarkan kesimpulan penelitian ini, diajukan beberapa saran bagi peneliti selanjutnya, diharapkan dapat mengkaji masalah dengan jangkauan yang lebih luas demi perkembangan ilmu pengetahuan dalam dunia penelitian, yaitu hendaknya pada penelitian selanjutnya dapat mencoba menggunakan model dan media pembelajaran yang variatif dan efisien lainnya untuk memaksimalkan hasil belajar, ataupun dapat menggunakan model Student Facilitator and Explaining berbantu media Papan Kartu Tempel untuk meningkatkan hasil belajar siswa dalam pembelajaran tematik di sekolah.

\section{DAFTAR PUSTAKA}

Arikunto, Suharsimi. 2013. Prosedur Penelitian: Suatu
Pendekatan Praktik. Jakarta: Rineka Cipta.

Daryanto. 2016. Media Pembelajaran Peranannya Sangat Penting dalam Mencapai Tujuan Pembelajaran Edisi ke-2 Revisi. Yogyakarta: Gava Media.

Departemen Pendidikan Nasional. 2003. Undang-Undang No. 20 Tahun 2003 Tentang Sistem Pendidikan Nasional. Jakarta: Depdiknas

Dian Idata Tarenda, Qoriati Mushafanah, dan Muhajir. 2018. Keefektifan Model Pembelajaran Student Facilitator and Explaining Berbantu Media Diorama Terhadap Hasil Belajar Mata Pelajaran IPS Siswa Kelas III SD Negeri 3 Purwareja Klampok. Jurnal Guru Kita (JGK): Vol 2 (3), 94-99.

Huda, Miftahul. 2013. Model-Model Pengajaran dan Pembelajaran. Yogyakarta: Pustaka Pelajar.

Pemerintah Republik Indonesia. 2013. Peraturan Pemerintah Republik Indonesia Nomor 32 Tahun $2013 \quad$ Tentang Perubahan Atas Peraturan Pemerintah Nomor 19 Tahun 2005 Tentang Standar Nasional Pendidikan. Jakarta.

Shoimin, Aris. 2014. 68 Model Pembelajaran Inovatif dalam Kurikulum 2013. Yogyakarta: Ar-Ruzz Media. 
Jurnal Sinektik

Volume 2 Nomor 2, Edisi Desember 2019

Prodi PGSD Universitas Slamet Riyadi

ISSN 2620-6560 (print) ISSN 2620-746X (online)

Sugiyono. 2016. Metode Penelitian

Pendidikan (Pendekatan

Kuantitatif, Kualitatif, dan

$R \& D)$. Bandung: Alfabeta. 